\title{
Problematika Pembelajaran Tahfidz di Pondok Pesantren
}

\section{Tahfidz Learning Problematics at Islamic Boarding School}

\section{Syafruddin Amir, Muhammad Ridwan Fauzi \& Muhammad Isomudin}

Sekolah Tinggi Agama Islam (STAI) Syamsul 'Ulum Gunungpuyuh

Sukabumi, Jawa Barat, Indonesia

syafruddinamir@staisyamsululum.ac.id, mridwanf@ staisyamsululum.ac.id \&

\section{isomuddin3@gmail.com}

\begin{abstract}
Abstrak
Tahfidz al-Qur'an merupakan suatu proses menjaga dan melestarikan kemurnian kitab suci al-Qur'an. Penelitian ini bertujuan untuk mengetahui problematika pembelajaran tahfidz al-Qur'an dengan memberikan solusi dalam mengatasi masalah tersebut. Penelitian ini dilaksanakan di Pondok Pesantren Syamsul 'Ulum dengan menggunakan pendekatan kualitatif dan metode deskriptif. Teknik pengumpulan datanya yaitu observasi, wawancara dan dokumentasi. Wawancara dilakukan kepada beberapa ustadz dan santri Pondok Pesantren Syamsul 'Ulum. Kemudian data yang terkumpul, dianalisis dengan teknik analisis data kualiatatif. Dari hasil penelitian ini ditemukan bahwa: 1) Pembelajaran tahfidz al-Qur'an merupakan salah satu program unggulan pondok pesantren Syamsul 'Ulum yang menggunakan metode talaqqi dalam pelaksanaannya, 2) Problematika pembelajaran tahfidz alQur'an di pondok pesantren Syamsul 'Ulum adalah rasa malas, kurang fokus, banyak kegiatan, faktor waktu, kurang pembimbing dan faktor lingkungan 3) Solusi untuk mengatasi problematika pembelajaran tahfidz adalah melawan malas dengan motivasi, memberi target hafalan yang jelas, mengurangi kegiatan ekstrakurikuler sekolah, dan memisahkan asrama Kata kunci: Problematika, Tahfidz al-Qur'an, Pesantren
\end{abstract}

\section{Abstract}

Tahfidzal-Qur'an is a process of maintaining and preserving the purity of the holy Qur'an. This research aims to determine the learning of tahfidzal-Qur'an at the Islamic boarding school with the find out solutions to solve that problems. This research was carried out at the Syamsul 'Ulum Islamic Boarding School uses a qualitative approach and descriptive method. The data collection techniques were observation, interview and documentation. Interviews were conducted with several ustadz and students of the Syamsul 
Problematika Pembelajaran Tahfidz di Pondok Pesantren

\& Muhammad Isomudin)

'Ulum Islamic boarding school. From the results of this research was found that: 1) Learning tahfidz al-Qur'an was one of the excelent programs of the Syamsul 'Ulum Islamic boarding school which uses the talaqqi method in its implementation, 2) the problems of learning tahfidz al-Qur'an in the Syamsul' Ulum Islamic boarding school were laziness, not focus, a lot of activities, time factors, lack of guidance and environmental factors 3) The solutions to solve the learning problems of tahfidz were fight laziness with motivation, provide clear memorization targets, reduce extracurricular school activities, and separate dorm

Keywords: Problematics, Tahfidz al-Qur'an, Islamic Boarding Schools

\section{PENDAHULUAN}

Al Qur'an merupakan Kalam Allah yang bernilai mukjizat, yang diturunkan kepada penutup para nabi dan rasul, dengan perantaraan Malaikat jibril, diriwayatkan dengan mutawattir, membaca terhitung sebagai ibadah dan tidak akan ditolak kebenarannya (AlHafidz, 2020).

Al-Qur'an diturunkan dalam bahasa Arab yang menjadi bahasa kesatuan untuk umat Islam. Sehingga amat mudah diketahui jika al-Qur'an ditambah isinya, atau dikurangi atau diubah. Walaupun itu satu harakat pun akan mudah diketahui. Bahasa Arab dengan berbagai disiplin ilmu yang dimilikinya akan dengan mudah mengetahui perubahan yang ada dalam al-Qur'an (Ridwan Fauzi, 2019), sehingga sangat sulit bagi musuh Islam untuk merusak isi alQur'an.

Tidak ada bacaan seperti AlQur'an yang dipelajari bukan hanya susunan redaksi dan pemilihan kosakatanya, tetapi juga kandungannya yang tersurat, tersirat bahkan sampai kepada kesan yang ditimbulkannya. Semua dituangkan dalam jutaan jilid buku, generasi demi generasi. Al-Qur'an layaknya sebuah permata yang memancarkan cahaya yang berbeda-beda sesuai dengan sudut pandang masingmasing.

Al-Qur'an memiliki melodi indah yang mampu menawan hati dan telinga si pendengar serta menjadikannya kokoh dalam hati nurani manusia dengan petunjuknya. Ketika pikiran manusia mencari bimbingan atau petunjuk melalui al-Qur'an, 
niscaya dia akan menjadi cahaya yang menerangi manusia untuk menemukan rahasia kehidupan dan alam semesta, membimbingnya untuk menemukan Allah melalui pengetahuan yang diperoleh kemudian meyakininya (Ahmad, 2018).

Terpeliharanya al-Qur'an ini menjadi bukti janji dari Allah bahwa al-Qur'an akan terpelihara keasliannya. Sebagaimana janji Allah dalam surat al-Hijr ayat 9:

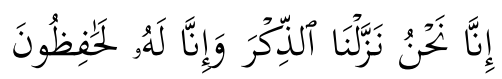

"Sesungguhnya Kamilah yang menurunkan al-Qur'an dan sesungguhnya Kami benar-benar memeliharanya." (QS. Al-Hijr [15]: 9)

$$
\text { Ayat ini merupakan }
$$
dorongan kepada orang-orang kafir untuk memercayai al-Qur'an sekaligus memutus harapan mereka untuk dapat mempertahankan keyakinan sesat mereka. Betapa tidak, al-Qur'an daan nilai-nilainya tidak akan punah tetapi akan bertahan. Itu berarti bahwa kepercayaan yang bertentangan dengannya, pada akhirnya pasti akan dikalahkan oleh ajaran alQur'an. Dengan demikian, tidak ada gunanya mereka memeranginya dan tidak berguna pula mempertahankan kesesatan mereka (Shihab ,2005).

Al-Qur'an sebagai mukjizat yang sempurna dan akan tetap dipertahankan dengan perintah Allah sampai hari kiamat. Siapapun yang hidup setelah wafatnya Nabi Muhammad S.A.W akan dapat melihat dan membacanya dengan tidak ada perubahan (Ahmad, 2018).

Saat ini telah banyak orangorang yang berusaha menghafal alQur'an, dari kalangan anak-anak hingga orang-orang dewasa, telah banyak yang berusaha untuk menghafalkan al-Qur'an. Bahkan Lembaga-lembaga tahfidz alQur'an sudah mulai bertambah, mereka berlomba menghafalkan alQur'an.

Orang-orang yang hafal alQur'an itu orang yang istimewa, mulia, selalu dipenuhi kebaikan, dan nanti pada hari kiamat akan mendapatkan kedudukan yang tinggi di surga sesuai dengan jumlah kalimat yang dibaca dan dihafalkannya (Yusuf, 2009). Mereka akan selalu dihormati di tengah-tengah masyarakat.

Orang yang menghafal alQur'an tidak terbatas pada orang yang mampu berbahasa Arab, tidak terbatas pada orang dewasa. 
Penghafal al-Qur'an tidak terbatas pada bangsa tertentu atau kelompok tertentu. al-Qur'an mampu dihafal oleh orang yang tidak memahami bahasa Arab, bahkan banyak anak-anak yang sudah mampu menghafal alQur'an.

Oleh karena itu saat ini telah banyak berdiri lembaga-lembaga tahfidz. Ada yang berbentuk pondok pesantren tahfidz, ada juga yang mendirikan rumah tahfidz. Lembaga-lembaga tahfidz berdiri dengan tujuan menampung keinginan sebagian orang tua yang ingin mencetak anaknya menjadi seorang penghafal al-Qur'an. Dengan memasukkan anaknya ke lembaga tahfidz, mereka berharap anaknya bisa dengan mudah menghafalkan al-Qur'an dan juga menjaga hapalannya.

Pondok pesantren Syamsul 'Ulum Gunungpuyuh Kota Sukabumi merupakan salah satu pondok yang memiliki program hafalan al-Qur' an atau yang disebut juga tahfizh al-Qur'an. Di pondok ini memiliki banyak kegiatan seperti pesantren tahfidz lainnya, bagi santri yang memilih program tahfidz mereka lebih difokuskan pada kegiatan menghafal al-Qur'an dan kajian tafsir al-Qur'an. Hal ini diharapkan agar para santri lebih fokus dan lebih giat lagi dalam menghafal al-Qur'an. Para santri yang mengikuti program tahfidz sebagian besar adalah siswa-siswi MTs dan MA Syamsul 'Ulum dan ada juga dari kalangan mahasiswa STAI Syamsul 'Ulum. Pondok pesantren ini terletak di Jl. Bhayangkara No.33

Kelurahan/Kecamatan

Gunungpuyuh Kota Sukabumi.

Pondok pesantren Syamsul 'Ulum memiliki banyak kegiatan sebagaimana pondok pesantren lainnya, juga program pesantren yang berbeda, seperti pendidikan formal TPA, MTs, MA, Perguruan Tinggi, program pengajian secara Umum, program salafi, dan juga program tahfidz. Khusus untuk program tahfidz santri difokuskan pada kegiatan hafalan al-Qur'an dan kajian tafsir al-Qur'an saja. Hal ini dilakukan agar para santri bisa lebih fokus dan lebih giat lagi dalam menghafal dan menguasai kandungan yang ada di dalam alQur'an.

Menghafal bukan perkara yang mudah karena sebelum melakukan penelitian, peneliti telah melakukan observasi dengan pembimbing dan salah satu santri program tahfidz pondok pesantren 
Syamsul 'Ulum Kota Sukabumi, dan narasumber pun membenarkan hal itu. Info yang didapat dari narasumber yakni ada beberapa kesulitan yang dihadapi, terutama masalah waktu. Mereka masih sering keteteran membagi waktu dengan baik. Sedangkan menghafal al-Qur'an itu membutuhkan waktu yang cukup. Masalah ini terutama bagi santri yang sekaligus menjadi mahasiswa.

Dengan melihat kenyataan di atas, penulis semakin tertarik untuk mendalami, mengangkat dan mengadakan penelitian dalam bidang tahfidz al-Qur'an. Dalam hal ini, penulis mengfokuskan pada program tahfidz di pondok pesantren Syamsul 'Ulum Gunungpuyuh Kota Sukabumi, dengan judul "Problematika Pembelajaran Tahfidz al-Qur'an Di Pondok Pesantren Syamsul 'Ulum Gunungpuyuh Kota Sukabumi."

\section{METODE PENELITIAN}

Penelitian menggunakan pendekatan kualitatif yang bersifat deskriptif kualitatif. Dikatakan deskriptif kualitatif karena penelitian ini bertujuan untuk mendeskripsikan hasil pengolahan data yang berupa kata-kata, gambaran umum yang terjadi di lapangan. Hal tersebut sebagaimana menurut Saodih (2012) bahwa penelitian kualitatif adalah suatu penelitian yang digunakan untuk mendeskripsikan dan menganalisis fenomena, peristiwa, aktifitas sosial, sikap kepercayaan persepsi, pemikiran orang secara individual maupun kelompok.

Sumber data ada dua macam, yaitu sumber data primer dan sumber data sekunder.Data primer didapat melalui wawancara kepada pengasuh, pengurus, ustadz, dan santri pondok pesantren Syamsul 'Ulum Gunungpuyuh Kota Sukabumi. Sedangkan. Sedangkan data sekunder yang digunakan adalah dokumen-dokumen, foto, rekaman video, rekaman suara, dan semua yang dapat mendukung sumber data primer.

Dalam pengumpulan data peneliti menggunakan tiga teknik, yaitu dengan observasi, wawancara dan dokumentasi. Kemudian data yang terkumpul, dianalisis dengan teknik analisis data kualiatatif yang memiliki 3 komponen utama yaitu reduksi data, penyajian data dan penarikan serta penyajian kesimpulan. 


\section{HASIL PENELITIAN DAN PEMBAHASAN}

\section{A. Bentuk Pembelajaran Tahfidz} di Pondok Pesantren Syamsul 'Ulum Kota Sukabumi

1. Pembelajaran Tahfidz di Pondok Pesantren Syamsul 'Ulum Kota Sukabumi

Program tahfidz al-Qur'an merupakan salah satu program pendidikan unggulan yang diselenggarakan oleh Pondok Pesantren Syamsul 'Ulum Gunungpuyuh Sukabumi. Program ini mulai berjalan pada tahun ajaran 2007-2008. Dalam pembelajaran tahfidz, santri juga mendapatkan pembelajaran tahsin dan tajwid untuk memperbaiki bacaannya.

Santri yang mengikuti program tahfidz berasal dari berbagai jenjang pendidikan yang ada di pondok pesantren Syamsul 'Ulum, dari siswa MTs, MA, SMK, sampai tingkat perguruan tinggi. Mereka mengikuti program tahfidz di luar jam kegiatan belajar di sekolah.

Sedangkan jadwal kegiatan pembelajaran tahfidz yaitu pagi hari setelah shalat Subuh sampai pukul 07.00, pukul 16.00-17.00 dan pukul 20.30-10.30.

\section{Metode Menghafal yang Diterapkan}

Dalam bahasa Arab, metode ini dikenal dengan istilah thariqoh yang berarti langkah-langkah strategis mempersiapkan untuk melakukan suatu pekerjaan (Ramayulis, 2004). Selain kata thariqoh, juga sering diungkapkan dengan istilah al-manhaj dan alwasilah yang berarti sistem dan perantara atau mediator. Tetapi dua kata terakhir ini tidak terlalu banyak digunakan. Dengan demikian, kata yang paling banyak digunakan adalah at-thariqoh, dan istilah ini yang banyak ditemui dalam al-Qur'an. Menurut Fuad alBaqy, dalam al-Qur'an kata atthariqoh diulang sebanyak sembilan kali.

Maka definisi mengenai metode pembelajaran al-Qur'an adalah sebuah cara yang dipergunakan oleh seorang pengajar kepada peserta didik dalam pembelajaran al-Qur'an yang berlangsung selama pembelajaran itu berjalan.

Dalam hal metode menghafal yang diterapkan di Pondok Pesantren Syamsul 'Ulum adalah metode talaqqi. Metode talaqqi adalah metode mengahafal yang dilakukan dengan cara 
menyetorkan

atau

memperdengarkan hafalan yang baru dihafal kepada seorang guru atau pembimbing. Metode ini dilakukan dengan tujuan untuk mengetahui hasil hafalan seorang penghafal al-Qur'an serta untuk mendapatkan bimbingan langsung dari guru. Sehingga hafalan santri selalu berada dalam pengawasan guru.

Dalam penelitian dari Haryani \& Sholeh (2019) menemukan bahwa terdapat pengaruh positif penerapan metode talaqqi terhadap peningkatan hafalan al-Quran peserta didik. Pun demikian metode ini tidak terlepas dari kelemahan yang dimilikinya, di antaranya yaitu murid kadang hanya menangkap verbalisme semata terutama mereka yang tidak mengerti terjemahan dari bahasa tertentu, mudah bosan ketika diajarkan tahfidz oleh gurunya dan kurang disiplinnya siswa dalam melakukan setoran hafalan kepada gurunya (Utami \& Maharani, 2018).

3. Pencapaian Pembelajaran Tahfidz

Hafalan yang didapatkan setiap santri tidak sama, walaupun sama-sama sudah menjalani selama sekian tahun. Hafalan yang didapatkan santri sesuai dengan kemampuan menghafal yang dimiliki santri. Adapun hasil pembelajaran tahfidz santri pondok pesantren Syamsul 'Ulum dapat dilihat pada tabel berikut:

Tabel 3 Pencapaian Hafalan Santri Putra

\begin{tabular}{|c|l|c|c|}
\hline No & \multicolumn{1}{|c|}{ Nama } & Kelas & Jumlah Hafalan \\
\hline 1 & Cep Hilmi M. Syafe'i & X MA & $15 \mathrm{Juz}$ \\
\hline 2 & M. Alif Mus'ab Habibilah & IX MTS & $16 \mathrm{Juz}$ \\
\hline 3 & M Faqih Jam'an & XI MA & $10 \mathrm{Juz}$ \\
\hline 4 & Restu Dwi Alhan & STAI & $8 \mathrm{Juz}$ \\
\hline 5 & Muhammad Aziz & XI SMK & $6 \mathrm{Juz}$ \\
\hline 6 & M Khoerudin & XI MA & $11 \mathrm{Juz}$ \\
\hline 7 & Romal Azhari & XI MA & $10 \mathrm{Juz}$ \\
\hline 8 & Salman Alfarisi & VIII MTs & 9 Juz \\
\hline 9 & Sultan Aulia Pajrullah & XI MA & 12 Juz \\
\hline 10 & M Abdul Aziz &
\end{tabular}

Tabel 4 Pencapaian Hafalan Santri Putri

\begin{tabular}{|c|l|c|c|}
\hline No & \multicolumn{1}{|c|}{ Nama } & Kelas & Jumlah Hafalan \\
\hline 1 & Khida maratus S & & $10 \mathrm{Juz}$ \\
\hline 2 & Lamia & & $20 \mathrm{Juz}$ \\
\hline
\end{tabular}




\begin{tabular}{|c|l|c|c|}
\hline No & \multicolumn{1}{|c|}{ Nama } & Kelas & Jumlah Hafalan \\
\hline 3 & Lesvi Nurmala & MA & 11 Juz \\
\hline 4 & Nia Sari Dewi & & 14 Juz \\
\hline 5 & Rima Rahmawati & MA & $15 \mathrm{Juz}$ \\
\hline 6 & Siti Marwah & MA & $13 \mathrm{Juz}$ \\
\hline 7 & Siti Mutiah & & $11 \mathrm{Juz}$ \\
\hline 8 & Sri Rahayu & MA & $17 \mathrm{Juz}$ \\
\hline 9 & Syifa Agustian & MA & $13 \mathrm{Juz}$ \\
\hline
\end{tabular}

B. Problematika Pembelajaran Tahfidz di Pondok Pesantren Syamsul 'Ulum Kota Sukabumi

Berdasarkan hasil wawancara yang dilakukan penulis terhadap ustadz dan santri, penulis mengetahui problematika santri dalam program tahfidz al-Qur'an, diantaranya:

1. Rasa Malas

Malas merupakan salah satu penyakit yang sering dihadapi santri dalam menghafal al-Qur'an. Rasa malas sangat menghambat perolehan jumlah setoran, dan akan mengurangi jumlah hafalan yang akan diulang. Rasa malas hanya membuang-buang waktu. Abdul Aziz salah seorang santri menjelaskan:

"Saya udah mulai malas dan jenuh menghafal. Saya udah mau lulus, udah 5 tahun di sini." Dapat disimpulkan bahwa problematika pembelajaran tahfidz adalah rasa malas.
2. Kurang Fokus

Program tahfidz di Pondok Pesantren Syamsul 'Ulum bukan program yang takhashshus /terfokus. Hal ini menyebabkan pencapaian hafalan setiap santri menjadi tidak merata, karena tidak ada target yang jelas dan jadwal tahfidz yang terkadang diganti dengan kegiatan yang lain. Menghafal al-Qur'an itu membutuhkan kefokusan, tidak bisa dicampur dengan banyak kegiatan yang lain. Ustadzah Listy Zahra menjelaskan: "Problematika anak/santri tidak takhassus, yang namanya menghafal al-Qur'an itu membutuhkan kefokusan, apalagi di sini santri sambil sekolah."

3. Banyak kegiatan

$$
\text { Para ahli al-Qur'an }
$$
berpedoman bahwa orang yang menghafal al-Qur'an harus mengutamakan al-Qur'an, baagi mereka al-Qur'an adalah segalasegalanya. Tetapi dalam kenyataannya banyak kegiatan lain 
yang tidak bisa ditinggalkan. Seperti diungkapkan oleh Ustadzah Listy Zahra: "Santri tahfidz kebanyakan aktif di kegiatan ekstrakurikuler, seperti OSIS, marching band, pramuka, qosidah, dan kaligrafi."

Salman Alfarisi sbagai santri mengungkapkan: "Problematika yang dihadapi kesulitan menyambung hafalan karena banyak kesibukan di OSIS dan sebagai ketua kamar".

Siti Marwah sebagai santri juga mengungkapkan: "Terus kebagi waktu sama sekolah. Pulang sekolah sekitar jam 2. Habis itu masih makan, mandi dan sebagainya, gak sempat istirahat apalagi menghafal. Sehingga waktu jam 4 pas mau ngaji itu ngantuk, capek"

4. Faktor Waktu

$$
\text { Menghafal al-Qur'an }
$$

membutuhkan alokasi waktu yang banyak. Semakin banyak waktu untuk menghafal, maka akan semakin mudah menyelesaikan hafalan. Tanpa didukung waktu yang cukup, pencapaian hasil tahfidz sulit sesuai target. Muhammad Aziz seorang santri menjelaskan: "Sedangkan permasalahan yang utama yaitu masalah waktu."
5. Kurang Pembimbing

Dalam pembelajaran tahfidz, jumlah santri yang banyak tidak akan sanggup dipegang oleh seorang pembimbing. Semakin banyak pembimbing, akan semakin mudah membimbing santri. Ustadzah Listy Zahra memaparkan: "Dengan santri yang banyak, saya banyak mengorbankan waktu saya untuk tahfidz, karena waktu yang ada 1 jam untuk tahfidz tapi saya sering memakan waktu 2 jam. Saya berusaha bagaimana caranya agar santri putri yang berjumlah 70 orang itu bisa setor semua." Salman Alfarisi seorang santri juga memaparkan: "Membutuhkan pembimbing yang lebih perhatian, seperti alumni yang pernah mengajar tahfidz di sini."

6. Faktor Lingkungan

Faktor lingkungan mempunyai pengaruh yang besar terhadap kesuksen tahfidz. Santri tahfidz harus berada pada lingkungan yang sangat mendukung. Teman juga termasuk faktor lingkungan. Lingkungan yang ramai, atau teman yang sering ngajak bermain dan mengobrol, akan menghilangkan konsentrasi sehingga hilang fokus dan tidak semangat. 
Seperti dituturkan oleh Ustadz Jajang Rahmat: "Problematika yang paling besar pengaruhnya adalah faktor lingkungan. Santri terpengaruh oleh santri lain yang tidak ikut program tahfidz. Kedisiplinan santri masih kurang. Ketika pembimbing tahfidz menertibkan santri tahfidz, terkendala dengan santri kitab, santri tahfidz sering ikut-ikutan dengan santri kitab.”

Ustadzah Listy Zahra juga menjelaskan: "Masalah tempat/asrama. Walaupun sekarang santri tahfidz sudah dipisah kamar dengan santri lainnya, tapi kan tetep lingkungannya campur dengan santri yang lain"

Abdul Aziz seorang santri juga mengatakan: "Faktor lingkungan, lingkungannya belum pas untuk menghafal al-Qur'an."

Siti Marwah sebagai santri juga mengatakan: "Yang pertama lingkungan. Karena di sini ada kitabnya, jadi kita sering kebawa sama teman."

\section{Solusi Untuk Mengatasi Problematika Pembelajaran Tahfidz di Pondok Pesantren Syamsul 'Ulum Kota Sukabumi}

Dalam segala hal, pasti memiliki problematika dan tantangan tersendiri. Begitu pula ketika seseorang ingin menjadi seorang hafidz, pasti memiliki problematika yang dihadapi. Dan setiap permasalahan pasti ada solusi tersendiri untuk mengatasinya. Sedangkan solusi untuk mengatasi problematika pembelajaran tahfidz di pondok pesantren Syamsul 'Ulum adalah sebagai berikut:

1. Melawan Malas dengan Motivasi

Adapun solusi untuk mengatasi problematika malas adalah dengan motivasi dari diri sendiri, keluarga, dan guru atau ustadz. Kemalasan bisa dilawan dengan kemauan yang kuat. Kemalasan harus diberantas dengan dipaksa, karena kemalasan merupakan sumber kegagalan. Dengan motivasi terutama dari diri sendiri dan didorong dari kelurga dan ustadz, kemalasan akan mudah teratasi.

2. Memberi Target Hafalan yang Jelas

Dengan memberi target hafalan kepada santri , program tahfidz di pondok pesantren Syamsul 'Ulum menjadi lebih terprogram dan terencana. Santri 
akan terdorong untuk mengejar target yang telah ditentukan. Jika tidak ditentukan target hafalan, santri tidak mempunyai beban untuk mencapai target, sehingga bisa membuat santri jenuh dan malas.

3. Mengurangi

Kegiatan

Ekstrakurikuler Sekolah

Santri hendaknya mengurangi keikutsertaan di ekstrakurikuler. Semakin sering santri mengikuti kegiatan ekstrakurikuler, maka semakin berkurang waktu dan tenaganya untuk menghafal, serta pikiran akan cepat kecapean. Sebab, menghafal al-Qur'an itu membutuhkan waktu yang ekstra, tenaga, dan pikiran yang jernih.

4. Memisahkan Asrama Santri Tahfidz

Seorang hafidz al-Qur'an seharusnya berada di lingkungan yang sesuai dengan program tahfidz, atau bergabung dengan sesama orang yang sedang menghafal al-Qur'an. Karena lingkungan sangat berpengaruh terhadap santri tahfidz.

\section{PENUTUP}

Berdasarkan hasil penelitian dapat diambil kesimpulan bahwa pondok pesantren menghadapi beberapa problematika dalam pembelajaran tahfidz di antaranya yaitu rasa malas, kurang fokus, banyak kegiatan, faktor waktu, kurang pembimbing dan faktor lingkungan. Solusi untuk mengatasi problematika tersebut yaitu dengan melawan malas dengan motivasi, memberi target hafalan yang jelas, mengurangi kegiatan ekstrakurikuler sekolah, dan memisahkan asrama santri tahfidz.

\section{DAFTAR PUSTAKA}

Ahmad, Yusuf Al-Hajj. (2018). Mukjizat Al-Qur'an Yang Tak Terbantahkan. Kartasura: PT Aqwam Media Profetika.

Alfarisi, Salman. (2020). Hasil Wawancara Santri Ponpes Syamsul 'Ulum: Sukabumi, 25 Juli 2020.

Al-Hafidz, Ahsin Wijaya. (2000). Bimbingan praktis menghafal al-Qur'an. Wonosobo: penerbit Amzah.

Aziz, Abdul. (2020). Hasil Wawancara Santri Ponpes Syamsul 'Ulum: Sukabumi, 25 Juli 2020 
Haryani, Leni Dwi \& Sholeh, Muhtar Arifin. (2019). Efektivitas Metode Talaqqi Dalam Meningkatkan Hafalan Alqur'an Peserta Didik Di Sdit Ulul Al-Bab Weleri. Ta'dibuna: Jurnal Pendidikan Agama Islam, 2 (2), 47-52.

Marwah, Siti. Hasil Wawancara Santri Ponpes Syamsul 'Ulum: Sukabumi, 25 Juli 2020

Mulyana, Jajang Rahmat. Hasil Wawancara Pembimbing Tahfidz Ponpes Syamsul 'Ulum: Sukabumi, 24 Juli 2020

Ridwan Fauzi, Muhammad. (2019). Implementasi Metode Langsung dalam Pembelajaran Bahasa Arab di Pondok Pesantren Syamsul 'Ulum Sukabumi. Tarbiyatu Wa Ta'lim: Jurnal Pendidikan Agama Islam, 01 (1), 1-13.

Saodih, Nana. (2012). Metode Penelitian Pendidikan. Bandung: Remaja Rosdakarya.

Shihab, M. Quraish. (2005). Tafsir Al-Mishbah Volume 14. Jakarta: Penerbit Lentera Hati.

Utami \& Maharani. (2018). Kelebihan dan Kelemahan Metode Talaqqi dalam Program Tahfidz al-Qur'an Juz 29 dan 30 pada Siswa Kelas Atas Madrasah Ibtidaiyah Muhammadiyah. Jurnal Profesi Pendidikan Dasar, 5 (2), 185-192.

Yusuf , Ahmad Muhammad. (2009). Ensiklopedia Tematis Ayat Al-Qur'an dan Hadits Jilid 3. Jakarta: Widya Cahaya.

Zahra, Listy. (2020). Hasil Wawancara Pembimbing tahfidz ponpes Syamsul 'Ulum: Sukabumi, 24 Juli 2020. 